Crop Breeding and Applied Biotechnology 10: 321-328, 2010

Brazilian Society of Plant Breeding. Printed in Brazil

\title{
Detection of QTL associated with rust resistance using IBD-based methodologies in exogamic E ucal yptus spp. populations
}

Tatiana Barbosa Rosado ${ }^{1 *}$, Rafael Simões Tomaz ${ }^{1}$, Marcio Fernandes Ribeiro Junior ${ }^{1}$, Antônio Marcos Rosado ${ }^{2}$, Lúcio Mauro da Silva Guimarães ${ }^{1}$, Elza Fernandes de Araújo ${ }^{1}$, Acelino Couto Alfenas ${ }^{1}$ and Cosme Damião Cruz ${ }^{1}$

Received 20 February 2010

Accepted 14 May 2010

\begin{abstract}
In Brazil the rust caused by Puccinia psidii Winter stands out as the most important disease of eucalyptus. The use of resistant genotypes is the main control method, which makes the detection of markers linked to rust resistance essential to the selection of resistant genotypes. In this study, an $F_{1}$ progeny of 131 plants from interspecific crossings of Eucalyptus was used to identify markers linked to resistance genes for this pathogen. An integrated map was constructed for linkage group three based on microsatellite markers. For QTL mapping two methodologies based on alleles identical-by-descent (IBD) were used: single marker analysis of Haseman and Elston and the interval mapping procedure of Fulker and Cardon. Both methods showed significant association for the Embra 125 marker.The QTL that explained $42 \%$ of the phenotypic variation was mapped to 0.02 cM of this marker by the Fulker and Cardon. Marker Embra 125 has potential use in assisted selection, thus increasing the efficiency of the selection of resistant genotypes.
\end{abstract}

Key words: Eucalyptus grandis, Eucalyptus urophylla, Puccinia psidi, QTL mapping, molecular marker.

\section{INTRODUCTION}

Eucalyptus is one of the most important genera for the cellulose and paper industries, besides its good adaptability and standing at the beginning of its domestication. These aspects awaken the interest for a better yield, product quality, and disease and stress resistant perspective (Picoli et al. 2004). Rust (Puccinia psidii Winter) is one of the most severe diseases of eucalyptus in Brazil (Alfenas et al. 2003). The most effective control method for rust of eucalyptus is genetic selection for resistance (Booth et al. 2000, Glen et al. 2007), identifying genes/QTLs is essential for breeding programs. Nevertheless only one study of gene mapping for rust has been performed until today (Junghans et al. 2003a). In this study, a gene, named Ppr-1, was mapped with RAPD markers in a family of full siblings of Eucalyptus grandis. Junghans et al. (2003a) demonstrated that the marker RAPD AT9/917 is completely linked to the gene Ppr-1 and suggested the potential use of this marker in assisted selection. However, because of the limitations inherent to the RAPD technique, use of the linkage information about Ppr- 1 was restricted to the pedigree used in its mapping which limits the effective use of the AT9/917 marker in assisted selection.

A more effective strategy is mapping a large number of codominant multiallelic microsatellite (SSR) markers (Brondani et al. 2002, Ottewell et al. 2005, Brondani et al. 2006). The current availability of transferable SSR markers, makes it possible to determine the synteny of interspecific

\footnotetext{
${ }^{1}$ Universidade Federal de Viçosa, Departamento de Biologia Geral/BIOAGRO, 36570-000, Viçosa, MG, Brazil. *E-mail: tatianarosado@yahoo.com.br

${ }^{2}$ Celulose Nipo Brasileira S.A., Rodovia BR 381, km 172, 35196-000, Belo Oriente, MG, Brazil.
} 
QTLs, and facilitates the targeted search for new allelic variations in a QTL known inside and between eucalypt species, thus expanding the opportunities for introgression and marker-assisted selection (MAS) in the improvement by hybridization (Grattapaglia 2004). Through this strategy E. Mamani et al. (2010), employed the same E. grandis progeny used by Junghans et al. (2003a) and using microsatellite markers, verified the existence of factorial linkage between Ppr-1 and the microsatellite marker Embra 227 of linkage group three from the reference map of Eucalyptus (Brondani et al. 2006). Positioning Ppr-1 in the reference map opened up the possibility of carrying out searches for rust resistant genes in interspecific crossings with the microsatellite markers of linkage group three.

The studies of detection of genes/QTL associated with rust resistance (Junghans et al. 2003a, Mamani et al. (2010),) were performed using the information derived from pseudo-testcross maps which, in spite of its relevance in several mapping studies, has the disadvantage of segregating markers analyzed separately for each parent and excluding the markers that segregate in the proportion 1:2:1. In exogamic populations as Eucalyptus, as many as four alleles can be segregated for each marker locus and for the QTL, hindering the linkage analyses between marker pairs. In this case, it is necessary to employ methodologies and genetic delineations specific to exogamic populations for the complete use of genetic information.

Considering all the above, the purpose of this study was to test whether the resistance to rust in an interspecific family of Eucalyptus is controlled by the same genomic region that controls resistance to rust in $E$. grandis through a mapping strategy that has greater statistical power for identifying QTLs in exogamous populations.

\section{MATERIAL AND METHODS}

\section{Phenotyping}

An $F_{1}$ progeny of full siblings of 131 plants derived from an interspecific crossing $[(E$.grandis $) \mathrm{x}$ (E. urophylla x E. grandis)] was used. Greenhouse-grown eucalyptus seedlings (4-5 months old) were inoculated by spraying to run-off the upper and lower surface of the third and fourth apical leaves with $2 \times 104$ uredinio-spores $\mathrm{mL}^{-1}$ of a single pustule-isolate of $P$. psidii (UFV-2). This isolate was obtained from E. grandis in the State of São Paulo, and is available upon request. Inoculated plants were incubated for $24 \mathrm{~h}$ in a mist chamber at $25^{\circ} \mathrm{C}$ in the dark and then transferred to a growth chamber at $22^{\circ} \mathrm{C}$ and a 12 $\mathrm{h}$ photoperiod, at $40 \mathrm{mM}$ photons $\mathrm{m}^{-2} \mathrm{~s}^{-1}$ light intensity. Disease severity was evaluated 12 and 20 days after inoculation (d.a.i.) using the rating scale proposed by Junghans et al. (2003b), with four degrees of severity (S0 $=$ immune or hypersensitive reaction, with necrosis or fleck; $\mathrm{S} 1$ = punctiform pustules; $\mathrm{S} 2$ = medium-size pustules, with sporulation more abundant than in $\mathrm{S} 1$; and $\mathrm{S} 3=$ large pustules and intense sporulation on both leaf surfaces) (Table 1). For the QTL analysis the four phenotypic classes were considered separately, instead of converting it to a binary standard (resistant vs. susceptible). Thus, the techniques for QTL detection were applied to the data of one discrete, multicategoric variable.

\section{Genotypying of microsatellites}

Genotyping was based on pre-positioning of Ppr-1 on linkage group 3 by Mamani et al. (2010). The progeny was genotyped with 23 microsatellite (SSR) oligonucleotides belonging to linkage group three, developed by Brondani et al. (2006). Amplification reactions were performed according to Brondani et al. (2006) with modifications in the annealing temperature and in the time of the amplification cycles. The amplifications were carried out in a thermal cycler (Programmable Thermal Controller - 100, MJ Research Inc.) programmed for an initial step at $94{ }^{\circ} \mathrm{C}$ for 5 minutes, followed by 36 cycles with the following steps: 1 minute at $94{ }^{\circ} \mathrm{C}, 1$ minute at the temperature established for each oligonucleotide, and 1 minute at $72{ }^{\circ} \mathrm{C}$. After a final step of 7 minutes at $72{ }^{\circ} \mathrm{C}$, the temperature was decreased to $4{ }^{\circ} \mathrm{C}$ until samples were collected.

Table 1. Segregation of rust resistance in F1 progeny $7074 \times 1213$ inoculated with $P$. psidii evaluated 12 days after inoculation and confirmed 20 days after inoculation

\begin{tabular}{|c|c|c|c|c|c|c|c|c|}
\hline \multirow{2}{*}{ Progeny } & \multicolumn{4}{|c|}{$\mathrm{Nr}$ of plants/Severity class } & \multirow{2}{*}{$\mathbf{R}: \mathbf{S}^{\mathbf{a}}$} & \multirow{2}{*}{$\begin{array}{c}\text { Expected } \\
\text { ratiob }\end{array}$} & \multirow{2}{*}{$\chi^{2}$} & \multirow{2}{*}{$P$ value } \\
\hline & S0: & S1: & S2: & S3 & & & & \\
\hline $7074 \times 1213$ & 36 & 23 & 25 & 47 & $59: 72$ & $1: 1$ & 0.9 & 0.35 \\
\hline
\end{tabular}

${ }^{a}$ Resistant:Susceptible ratio is based on $\mathrm{R}=\mathrm{S} 0+\mathrm{S} 1$ and $\mathrm{S}=\mathrm{S} 2+\mathrm{S} 3$.

${ }^{b}$ The resistance was hypothesized to be controlled by a major dominant gene. 


\section{Genetic mapping}

The SSR markers of linkage group three were mapped by integrating information from the parental meioses and the integrated map constructed with software Gqmol (Cruz 2009). The maximum recombination frequency of $30 \%$ and the minimum value of LOD ( $\log$ likelihood ratio) of 3.0 were the parameters used to determine linkage between markers. The distances between markers in $\mathrm{cM}$, were calculated using the Kosambi mapping function.

\section{Genetic mapping of QTLs}

QTL analyses were carried out from integrated maps previously constructed for linkage group three by the IBDbased methodologies described below. All analyses were performed with the software Gqmol.

\section{Single marker analysis proposed by Haseman and Elston (1972)}

This strategy bases on a regression in which the dependent variant $\left(Y_{j}\right)$ is determined by the square of the phenotypic difference among the individuals of the $j^{\text {th }}$ sibling pair, and the independent variant is given by the value of alleles identical-by-descent (IBD) of the considered sibling pair.

The adopted model was:

$Y_{j}=\beta_{0}+\beta_{1} \pi_{j}+\varepsilon_{j}$, in which

$Y_{j}=\left(X_{1 j}-X_{2 j}\right)^{2}$, with $X_{l j}$ and $X_{2 j}$ being the values observed for the characteristic in the first and second sibling of the $j^{\text {th }}$ pair;

$\pi_{j}=f_{j 1}+f_{j 2}$, with $f_{j 1}$ being the probability that the $j^{\text {th }}$ sibling pair has one IBD allele, and $f_{j 2}$, the probability that the $j^{\text {th }}$ sibling pair has two IBD alleles. $\beta_{0}$ and $\beta_{1}$ are the model parameters.

Since $X_{1 j}$ and $X_{2 j}$ are the values observed for the characteristic in the first and second siblings, respectively, in the $j^{\text {th }}$ pair the following general model was assumed:

$$
X_{1 j}=\mu+g_{1 j}+e_{1 j} \text { and } X_{2 j}=\mu+g_{2 j}+e_{2 j}
$$

in that: $\mu=$ average mean value; $g_{i j}=$ genetic effect associated to the individual $i$ of the $j^{\text {th }}$ sibling pair; $e_{i j}=$ environmental effect on the individual $i$ of the $j^{\text {th }}$ sibling pair.

In this model, it was assumed that the population is in Hardy-Weinberg equilibrium, and that only two alleles, $\mathrm{Q}_{1}$ and $\mathrm{Q}_{2}$, with frequencies $p$ and $q$, respectively, are involved in the determination of $g_{i j}$. Also the scale of genotypic values a, $d$ and - a, was assumed, for $Q_{1} Q_{1}$, $\mathrm{Q}_{1} \mathrm{Q}_{2}$ and $\mathrm{Q}_{2} \mathrm{Q}_{2}$, respectively.

Putting together the information of the square differences $\left(Y_{j}\right)$ and expected frequencies for each pair of siblings conditioned by $\pi_{j}$, it was possible to calculate the following expectation:

$$
E\left(Y_{j} \mid \pi_{j}\right)=\left(\sigma_{e}^{2}+2 \sigma_{A}^{2}\right)-2 \sigma_{A}^{2} \pi_{j}
$$

which can be rewritten by the model:

$$
E\left(Y_{j} \mid \pi_{j}\right)=\beta_{0}+\beta_{l} \pi_{j}
$$

in which

$$
\begin{aligned}
& \beta_{0}=\sigma_{e}^{2}+2 \sigma_{A}^{2} \\
& \beta_{l}=-2 \sigma_{A}^{2}
\end{aligned}
$$

Thus, knowing $\pi_{j}$ it is possible to adjust a linear equation by regression based on the model $\mathrm{E}\left(\mathrm{Y}_{\mathrm{j}} \mid \pi_{\mathrm{j}}\right)=\beta_{0}+\beta_{l} \pi_{\mathrm{j}}$, in which $-1 / 2 \beta_{l}$ is a non-biased estimator of $\sigma_{A}^{2}$.

When the QTL and marker are not completely linked, the expected IBD proportion of the QTL must be indirectly estimated by the marker IBD, whose information is available in molecular analyses. Thus, when substituting $\pi_{j}$ by $\hat{\pi}_{j}$, the following model is obtained:

$$
E\left(Y_{j} \mid \hat{\pi}_{j}\right)=\beta_{0}+\beta_{l} \hat{\pi}_{j}
$$

Considering the special case of the absence of dominance and complete information about the genitors, this is obtained:

$$
\beta_{l}=-2(1-2 r)^{2} \sigma_{A}^{2}
$$

in which $\mathrm{r}$ is the percentage of recombination among the marker loci and the controller of the analyzed characteristic.

A fraction of the QTL heritability was estimated with the following expression:

$$
h_{p}^{2}=(1-2 r)^{2} h^{2}=-\frac{\hat{\beta_{1}}}{2 \hat{\sigma}_{F}^{2}}
$$

in which, $\hat{\sigma}_{F}^{2}$ is the phenotypic variance of the characteristic

\section{Interval mapping proposed by Fulker and Cardon (1994)}

For application of this methodology, which is based on Haseman and Elston (1972), the IBD proportion of adjacent marks in a linkage group were used to estimate the proportion of IBD alleles of one possible QTL along 
the interval between the marks. The position that offers the best regression adjustment was assumed as the estimated QTL position in the linkage group. This way, it was possible to separately obtain estimates for the QTL effect on the additive genetic variance, as well as for its position.

This methodology is based on the use of estimates for $\hat{\pi}_{l j}$ and $\hat{\pi}_{2 j}$ in order to assess the proportion of IBD alleles among the sibling pairs for the locus Q, defined by, considering a value range for the recombination percentage between the loci $\mathrm{M}_{1}$ and $\mathrm{M}_{2}$. Estimation of $\pi_{q j}$ is done using the regression equation:

$$
\hat{\pi}_{q j}=\beta_{0}+\beta_{\pi l} \hat{\pi}_{1 j}+\beta_{\pi 2} \hat{\pi}_{2 j}+\varepsilon_{j}
$$

The solution for the system above is given by:

$$
\begin{aligned}
& \hat{\beta}_{\pi 1}=\frac{\left(1-2 r_{1}\right)^{2}-\left(1-2 r_{12}\right)^{2}\left(1-2 r_{2}\right)^{2}}{1\left(1-2 r_{12}\right)^{4}} \\
& \hat{\beta}_{\pi 2}=\frac{\left(1-2 r_{2}\right)^{2}-\left(1-2 r_{12}\right)^{2}\left(1-2 r_{2}\right)^{2}}{1\left(1-2 r_{12}\right)^{4}}
\end{aligned}
$$

and

$$
\beta_{0}=\overline{\hat{\pi}}_{q}-\hat{\beta}_{\pi 1} \overline{\hat{\pi}}_{1}-\hat{\beta}_{\pi 2} \overline{\hat{\pi}}^{2}=\left(1-\hat{\beta}_{\pi 1}-\hat{\beta}_{\pi 2}\right) / 2
$$

After obtaining the estimate of $\hat{\pi}_{q j}$ for a given position of the locus $\mathrm{Q}$, this value is used as an independent variable in the regression model $Y_{j}=\beta_{0}+\beta_{q} \pi_{q j}$. It is noted that, for a certain position between $\mathrm{M}_{1}$ and $\mathrm{M}_{2}$, estimates of $\hat{\pi}_{q j}$ must be obtained for $C_{n}^{2}$ combinations of sibling pairs. In this way, it is possible to perform the regression based on the values of $Y_{j \mathrm{j}}$ and $\hat{\pi}_{q j}$ estimated for each sibling pair.

For each value of $r_{1}$ and $r_{2}$, assumed inside the interval $r_{12}$ for the position of $Q$, an estimate of $\hat{\beta}_{q}$ is obtained based on the model $Y_{j}=\beta_{0}+\beta_{q} \pi_{q j}$. If this interval is divided $X$ times, there will be $X$ sets of estimates for $\hat{\beta}_{q}$. It is possible to perform $X$ regressions, permitting the choice of the equation inside the interval that shows the lowest sum of residual squares or with the highest adjustment $R^{2}$. At this position, the estimate for $\hat{\beta_{q}}$, which corresponds to the optimal criterion for choosing a regression equation, makes it possible to determine the $Q T L$ position and the contribution of the $Q T L$ for the additive variance $\sigma_{A}^{2}$ of the character, estimated by $-\beta_{q} / 2$.

So that a complete analysis of the linkage group three could be executed, it was enough to obtain estimatives of $\hat{\beta_{q}}$ for all the intervals in the group. These values were plotted on a graphic, setting the value of $R^{2}$ for the estimates $\hat{\beta}_{q}$ of on the ordinate axis, and the distance values in the intervals on the abscissa axis.
QTL heritability was estimated using the expression:

$$
h^{2}=\frac{\hat{\beta_{q}}}{2 \sigma_{F}^{2}} \text {, }
$$

with $\hat{\sigma}_{F}^{2}$ being the phenotypic variance of the studied characteristic.

The statistic F was used in order to evaluate the existence of QTLs in the intervals inside linkage group three. For declaration of the QTL the value of critical $\mathrm{F}=10.828$ and a significance level of $0.1 \%$ was adopted.

\section{Results and Discussion}

Out of the 23 markers that compose linkage group three of Eucalyptus, only seven amplified distinct and segregated alleles were in the analyzed progeny, thus being employed in the QTL detection. The distance estimated in $\mathrm{cM}$ of Kosambi between the marker loci is shown on Figure 1.

The total length of the linkage group three was $57.14 \mathrm{cM}$. The longest distance between two markers was $23.13 \mathrm{cM}$ and occurred between Embra 122 and Embra 189.

Using the methodology proposed by Haseman and Elston (1972), the variance of the phenotypic values was established as 1.7028 and IBD mean values, measured with SSR markers, varied from 0.50 to 0.65 , being near the expected for families of full siblings. The estimates of $\mathrm{F}$ were significant for markers Embra125, Embra181 and Embra227, with the highest $F$ value $(F=67.31)$ verified for marker Embra125. The results indicate that there is a relationship between the square of the phenotypic difference of individuals, taken in pairwise, and the IBD value for these markers. However, it is not distinguishable whether the existence of this relationship is due to high linkage of these markers with the QTL or to the high value of $\sigma_{A}^{2}$.

Additionally, it was possible to predict the estimate for the heritability fractions, dependent upon the distance between the marker and the QTL, associated to each marker locus (Table 2). It can be observed that the largest value of $h_{p}^{2}$ was estimated for the locus Embra125 (37\%), evidencing a possible linkage to the QTL responsible for rust resistance.

The method of Haseman and Elston (1972) has often been used in human genetics (Gray-McGuire et al. 2006, Wang and Elston 2006, Stein et al. 2007), where obtaining large families for genetic mapping is very difficult. In plants, this methodology is being applied for the first time at the 


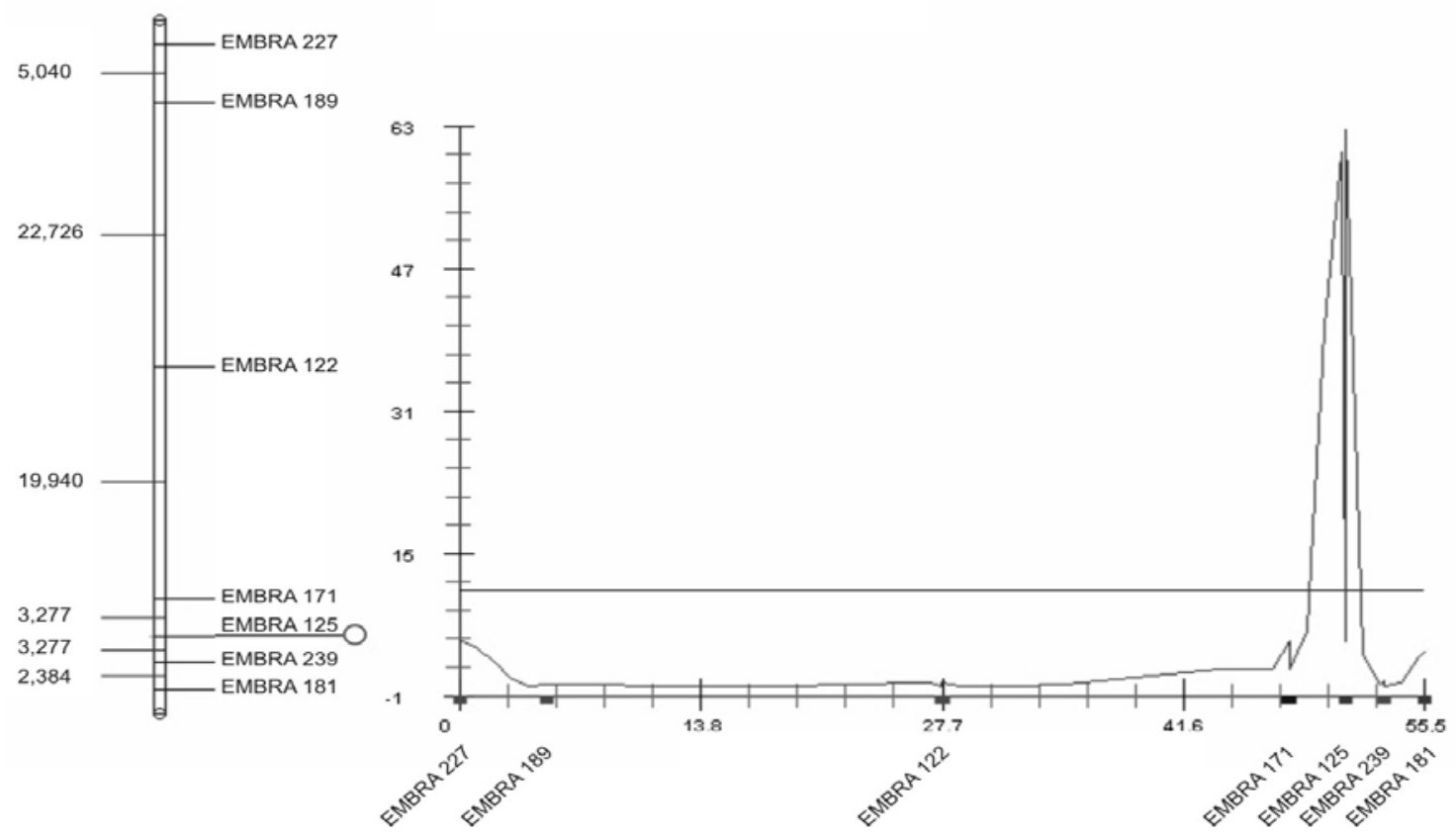

Figure 1. Display generated demonstrating the QTL for rust resistance, mapped employing the Fulker and Cardon regression, in linkage group three. Axis Y: F value; Axis X: intervals between the markers group three. The significance level defined was $0.1 \%(\mathrm{~F}=10.8)$.

Table 2. Coefficient of regression of Haseman and Elston (1972) in a family of full siblings of eucalyptus, genotyped with seven markers from linkage group three

\begin{tabular}{lccccccc}
\hline Markers & IBD & $\beta_{\boldsymbol{0}}$ & $\beta_{\boldsymbol{1}}$ & $\mathbf{R}^{\mathbf{2}(\boldsymbol{\%})}$ & $\mathbf{F}$ & Prob & $\boldsymbol{h}_{\boldsymbol{p}}^{\mathbf{2}}$ \\
\hline Embra 227 & 0.61 & 3.33 & 0.32 & 0.091 & 4.921 & $0.02^{*}$ & -0.09 \\
Embra189 & 0.65 & 3.59 & -0.07 & 0.009 & 0.353 & 1.0 & 0.02 \\
Embra122 & 0.63 & 3.70 & -0.25 & 0.049 & 2.674 & 0.10 & 0.07 \\
Embra171 & 0.52 & 3.58 & -0.71 & 0.002 & 0.10 & 1.0 & 0.20 \\
Embra125 & 0.51 & 4.19 & -1.27 & 1.653 & 67.31 & $0.0^{* *}$ & 0.37 \\
Embra239 & 0.51 & 3.36 & 0.06 & 0.004 & 0.1678 & 1.0 & -0.017 \\
Embra181 & 0.50 & 3.64 & -0.23 & 0.083 & 6.150 & $0.01^{*}$ & 0.067 \\
\hline
\end{tabular}

$\mathrm{h}_{p}^{2}=$ heritability fraction of the QTL *: value below the specified critical level $(5 \%)$.

present work. It was verified that it is possible to detect QTL in one single family of full siblings and that, despite not being possible to determine its position, this analysis is valid for an exploratory analysis of the data, especially when designing genetic linkage maps is not possible.

For the interval mapping procedure of Fulker and Cardon (1994), it was necessary to use the linkage information concerning the microsatellite loci of linkage group three (Figure 1). The results indicated that the position corresponding to Embra125 was the one that presented the highest value of $R^{2}(2.15 \%)$, and in this position the estimative of $\hat{\beta}_{q}$ was -1.45 . Thus, the additive variance at this point can be calculated using the estimate
$\sigma_{A}^{2}=\beta_{q} / 2=0.72$. Based on the phenotypic variance of the characteristic, it was possible to estimate the QTL heritability using $h_{Q}^{2}=\left(\hat{O}_{A}^{2} / \hat{O}_{F}^{2}\right) \times 100=42 \%$.

The method of Fulker and Cardon (1994), besides identifying the QTL effect on the additive variation, also identified the QTL position in linkage group three. This position is demonstrated by the graphic showing the value of the statistic F on the ordinate and, on the abscissa, the intervals between the markers contained in linkage group three (Figure 1), in cM. In this figure it can also be observed that the QTL was mapped very near the locus Embra125 (distance of $0.02 \mathrm{cM}$ ), between the markers Embra171 and Embra 239. 
The highest value of $\mathrm{R}^{2}(2.15 \%)$ obtained in the analysis of Fulker and Cardon (1994) is still low, when compared to the methods described for endogamic populations. However, these values are not comparable, because $\mathrm{R}^{2}$ in endogamic populations are estimated in a way that its value explains how much of the genetic variance accounts for the phenotypic variation of the characteristic. By analysis of Fulker and Cardon (1994), which considers exogamic populations, $\mathrm{R}^{2}$ represents how much the IBD variance explains the square of the phenotypic difference, that is, vector in this case is a square component that generates low, non-comparable $\mathrm{R}^{2}$.

QTL mapping by the strategy of Fulker and Cardon (1994) is also used very often in human genetics (Zhao 2000, Amos 2001, Gorlova et al. 2003). The methodology of Fulker and Cardon (1994) can be explored, not only in perennial plant species, for which obtaining classic mapping delineations is less feasible, but also in annual species for multiple families with many breeding generations (Yang et al. 2000). The main difficulty in this strategy would be the establishment of an integrated map that better explains the recombination frequencies of the markers in the different meiotic sets (crossings). However, the program Gqmol (Cruz 2009) already contains algorithms capable of executing the calculations of recombination frequency considering the simultaneous information concerning the meioses of both heterozygotic parents, in order to produce an integrated map.

In this study, the QTL for rust located using the interval mapping procedure of Fulker and Cardon (1994) was also identified using the methodology based in single marker analysis of Haseman and Elston (1972). This demonstrates that a portion of the variability in rust resistance is due to genetic effects, i.e. there is heterozygosity for the QTL and the alleles at these loci exhibit effects sufficiently different to be detected as significant in a small full-sib family. Both methods showed significant association on marker Embra 125.

The QTL that explained $42 \%$ of the phenotypic variation was mapped to $0.02 \mathrm{cM}$ of this marker by the interval mapping of Fulker and Cardon (1994). Junghans et al. (2003a) studying a family of full siblings of Eucalyptus grandis demonstrated that the AT9/917 RAPD marker is completely linked to the rust gene (Ppr-1). Mamani et al. (2010), using microsatellite markers, positioned the gene Ppr-1 in linkage group three of Eucalyptus, near the marker Embra $227(12 \mathrm{cM})$. In the present study, the genetic distance from the QTL to Embra 227 was $50 \mathrm{cM}$. Even though the crossing used in this study was different from that employed by Junghans et al. (2003a), the possibility that the resistance gene mapped is allelic to Ppr- 1 cannot be excluded, since these QTLs were identified in the same region of linkage group 3. Differences in position can be attributed to the different mapping strategies and differences in effect can be attributed to the fact that the QTL detected in the integrated mapping came from information of both parents whereas the QTL detected in the pseudo-testcross mapping came from information of only one parent. Indifferent, whether closely linked genes or alleles from the same gene, the existence of alleles for rust resistance in distinct species of $E$. grandis represents new genetic variability for breeding programs that aim at the development of eucalypt clones showing rust resistance.

We expect with this study that the marker Embra 125 has potential use in breeding programs based on markerassisted selection (MAS). The microsatellites flanking the QTL detected can be used as guides in selections assisted by markers, with the favorable alleles of this QTL being possibly selected. Furthermore, the physical proximity between the marker Embra 125 and the QTL for rust resistance, associated with the physical map and the complete genome sequencing of E. grandis (Eucagen 2009), will possibly be used in the accomplishment of positional cloning of resistance genes, intensifying the use of genetic manipulation in the molecular improvement of Eucalyptus

\section{Acknowledgments}

We thank the program of post-graduation in Genetics and Breeding of the Universidade Federal de Viçosa, for supporting the accomplishment of this work. Also the Conselho Nacional de Desenvolvimento Científico e Tecnológico (CNPq) and Fundação de Amparo à Pesquisa do Estado de Minas Gerais (FAPEMIG) for the financial support granted for the execution of this work. 


\title{
Detecção de QTL associado à resistência a ferrugem em populações exogâmicas de E ucalyptus spp. usando metodologias baseadas em IBD
}

\begin{abstract}
RESUMO - No Brasil, a ferrugem causada por Puccinia psidii Winter destaca-se como a mais importante doença do eucalipto. $O$ uso de genótipos resistentes é o principal método de controle, o que torna a detecção de marcadores ligados a resistência à ferrugem essencial para a seleção de genótipos resistentes. Neste estudo, uma progênie $F_{1}$ composta por 131 plantas derivadas de um cruzamento interespecífico de Eucalyptus.Um mapa integrado foi construído para o grupo de ligação três com base em marcadores microssatélites. Para detecção de QTL foram utilizadas duas metodologias baseadas em alelos idênticos por descendência (IBD): marca simples de Haseman and Elston e mapeamento por intervalo de Fulker and Cardon. Ambas as metodologias evidenciaram associação mais significativa para o marcador Embra 125. O QTL que explicou $42 \%$ da variação fenotípica foi mapeado a 0,02 cM desse marcador pela metodologia de intervalo de Fulker and Cardon. O marcador Embra125 têm potencial utilização em seleção assistida, com conseqüente aumento na eficiência durante a seleção de genótipos resistentes.
\end{abstract}

Palavras-chave: Puccinia psidii, Eucalyptus grandis, Eucalyptus urophylla, mapeamento de QTL, marcador molecular.

\section{REFERENCES}

Alfenas AC, Zauza EAV and Assis TF (2003) First record of Puccinia psidii on Eucalyptus globulus and E. viminalis in Brazil. Australas Plant Pathology 32: 325-326

Amos CI (2001) Genetic linkage methods for quantitative traits. Statistical Methods in Medical Research 10: 3-25.

Booth TH, Old KM and Jovanovic T (2000) A preliminary assessment of high risk areas for Puccinia psidii (Eucalyptus rust) in the Neotropics and Australia. Agriculture, Ecosystems and Environment 82: 295-301.

Brondani RPV, Brondani VC and Grattapaglia D (2002) Towards the construction of a genus wide reference linkage map for Eucalyptus based on microsatellite markers. Molecular and General Genomics 267: 338-347.

Brondani RPV, Williams ER, Brondani VC and Grattapaglia D (2006) A microsatellite-based consensus linkage map for species of Eucalyptus and a novel set of 230 microsatellite markers for the genus. BMC Plant Biology 6: 20. 1-16.

Cottewell KM, Donnellan SC, Moran GF and Paton DC (2005) Multiplexed microsatellite markers for genetic analysis of Eucalyptus leucoxylon (Myrtaceae) and their utility for ecological and breeding studies in other Eucalyptus species. Journal of Heredity 96: 445-451.

Cruz CD (2009) Gqmol: programa para análise de genética quantitativa molecular. Versão 2009.1.1. Available at www.ufv.br/ dbg/gqmol/gqmol.htm Assessed in December 2009.

Eucagen (2009) International Eucalyptus genome network. Available at www.ieugc.up.ac.za. Assessed in December 2009.

Fulker DW and Cardon LR (1994) A sib-pair approach to interval mapping of quantitative trait loci. American Journal of Human Genetics 5: 1092-1103.
Glen M, Alfenas AC, Zauza EAV, Wingfield MJ and Mohammed C (2007) Puccinia psidii: a threat to the Australian environment and economy - a review. Plant Pathology 36: 1-16.

Gorlova OY, Amos CI, Wang NW, Shete S, Turner ST and Boerwinkle E (2003) Genetic linkage and imprinting effects on body mass index in children and young adults and young adults. European Journal of Human Genetics 11: 425 432.

Grattapaglia D (2004) Integrating Genomics into Eucalyptus breeding. Genetics and Molecular Research 3: 369-379.

Gray-McGuire CR, Sinha S, Iyengar C, Millard BA, Rybicki RC, Elston MC, Iannuzzi and Saga SC (2006) Genetic characterization and fine mapping of susceptibility loci for sarcoidosis in African Americans on chromosome 5. Human Genetics 120: 420-430.

Haseman JK and Elston RC (1972) The investigation of linkage between a quatitative trait and a marker locus. Genetics 2: 319.

Junghans DT, Alfenas AC, Bromomonschenkel SH, Oda S, Mello EJ and Grattapaglia (2003a) Resistance to rust (Puccinia psidii Winter) in Eucalyptus: mode of inheritance and mapping of a major effect locus with RAPD markers. Theoretical applied genetics 108: 175-180.

Junghans DT, Alfenas AC and Maffia LA (2003b) Escala de notas para quantificação da ferrugem em Eucalyptus. Fitopatologia Brasileira 28: 184-188.

Lander ES and Botstein D (1989) Mapping mendelian factors underlying quantitative traits using RFLP linkage maps. Genetics 121: 185-199. 
Mamani EMC, Bueno NW, Faria DA, Guimarães LMS, Lau D, Alfenas AC and Grattapaglia D (2010) Positioning of the major locus for Puccinia psidii rust resistance (Ppr1) on the Eucalyptus reference map and its validation across unrelated pedigrees. Tree Genetics \& Genomes 6, p. 10.1007/s11295.

Picoli EAT, Alfenas AC, Cruz CD, Moura, DF, Dias LAS (2004) Sample size for number of RAPD markers to estimate genetic diversity in Eucalyptus. Crop Breeding and Applied Biotechnology 4: 384-390.

Stein CM, Zalwango S, Chiunda AB, Millard C, Leontiev DV, Horvath A, Lcartier KC, Chervenak K, Boom WH, Elston RC, Mugerwa RD, Whalen CC and Iyengar S (2007) Linkage and association analysis of candidate genes for TB and TNFa cytokine expression: evidence for association with IFNGR1, IL-10, and TNF receptor 1 genes. Human Genetics 121 : $663-673$.
Wang T and Elston RC (2006) A quantitative linkage score for an association study following a linkage analysis. BMC Genetics 7: $5-12$

Yang DA, Vanrraden PM and Schook LB (2000) Detection and parameter estimation for quantitative trait loci using regression models and multiple markers. Genetics Selection Evolution 32: $357-381$.

Zhao H (2000) Family-based association studies. Statistical Methods in Medical Research 9: 563-587. 